\title{
UV Photodissociation of Proline-containing Peptide lons: Insights from Molecular Dynamics
}

\author{
Marion Girod, ${ }^{1,2}$ Zeljka Sanader, ${ }^{3}$ Marin Vojkovic, ${ }^{1,4}$ Rodolphe Antoine, ${ }^{1,4}$ \\ Luke MacAleese, , ${ }^{1,4}$ Jérôme Lemoine, ${ }^{1,2}$ Vlasta Bonacic-Koutecky, ${ }^{3,5}$ Philippe Dugourd ${ }^{1,4}$ \\ ${ }^{1}$ Université de Lyon, F-69622, Lyon, France \\ ${ }^{2}$ Institut des Sciences Analytiques, CNRS et Université Lyon 1 UMR 5280, Lyon, France \\ ${ }^{3}$ Interdisciplinary Center for Advanced Science and Technology (ICAST) at University of Split, Split, Croatia \\ ${ }^{4}$ Institut Lumière Matière, Université Claude Bernard Lyon 1, CNRS UMR 5306, Lyon, France \\ ${ }^{5}$ Institut fur Chemie, Humboldt-Universität Berlin, Berlin, Germany
}

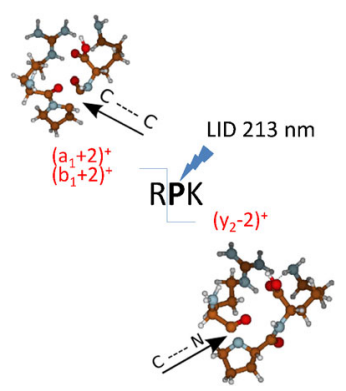

Abstract. UV photodissociation of proline-containing peptide ions leads to unusual
product ions. In this paper, we report laser-induced dissociation of a series of proline-
containing peptides at $213 \mathrm{~nm}$. We observe specific fragmentation pathways corre-
sponding to the formation of $(\mathrm{y}-2),(\mathrm{a}+2)$ and $(\mathrm{b}+2)$ fragment ions. This was not
observed at $266 \mathrm{~nm}$ or for peptides which do not contain proline residues. In order to
obtain insights into the fragmentation dynamics at $213 \mathrm{~nm}$, a small peptide (RPK for
arginine-proline-lysine) was studied both theoretically and experimentally. Calcula-
tions of absorption spectra and non-adiabatic molecular dynamics $(\mathrm{MD})$ were made.
Second and third excited singlet states, $\mathrm{S}^{2}$ and $\mathrm{S}^{3}$, lie close to $213 \mathrm{~nm}$. Non-adiabatic
MD simulation starting from $\mathrm{S}^{2}$ and $\mathrm{S}^{3}$ shows that these transitions are followed by C$\mathrm{C}$ and $\mathrm{C}-\mathrm{N}$ bond activation close to the proline residue. After this first relaxation step, consecutive rearrangements and proton transfers are required to produce unusual $(y-2),(a+2)$ and $(b+2)$ fragment ions. These fragmentation mechanisms were confirmed by $\mathrm{H} / \mathrm{D}$ exchange experiments.

Key words: Photodissociation, Proline-containing peptides, Fragmentation, Molecular dynamics, H/D exchange

Received: 4 July 2014/Revised: 27 October 2014/Accepted: 27 October 2014/Published Online: 11 December 2014

\section{Introduction}

$\mathrm{T}$ andem mass spectrometry (MS/MS) is a widely-used method to determine the amino acid sequence of peptides and proteins [1]. In addition, the use of CID (collision-induced dissociation) continues to be important in peptide sequencing and protein identification. In solution, the most basic site on a peptide devoid of histidine, lysine, and arginine residues is the nitrogen atom of the N-terminal amino group [2]. However, once the protonated peptide ion is desorbed into the gas phase, e.g. via electrospray, there is competitive transfer of the "ionizing" proton to amidic functional groups, the carbonyl oxygen and amidic nitrogen atoms on the backbone [3-8]. The peptide

Electronic supplementary material The online version of this article (doi:10.1007/s13361-014-1038-1) contains supplementary material, which is available to authorized users.

Correspondence to: Marion Girod; e-mail: marion.girod@univ-lyon1.fr, Philippe Dugourd; e-mail: philippe.dugourd@univ-lyon1.fr then fragments at the protonated peptide bond $[9,10]$. A nonterminal residue has two adjacent peptide linkages, one to the $\mathrm{N}$-terminal and the other to the C-terminal. At low $(<100 \mathrm{eV})$ energy CID, the protonated peptides fragment along the backbone at the amide bonds, and the mass spectrum typically consists of a series of $b, a$, and $y$ fragment ions. These fragments give valuable information $[9,10]$ concerning peptide sequence, number and location of disulfide bridges, identification and sometimes characterization of post-translational modifications. However, fragmentation pathways of protonated peptides are difficult to understand and known only at the phenomenological level.

It is apparent from the diverse CID patterns observed that the fragmentation routes of protonated peptides depend significantly on the identity and positions of the amino acids constituting the peptides. It was found that proline (Pro) and to a smaller extent glycine and serine residues tend to fragment at their $\mathrm{N}$-terminal peptide bonds, whereas residues such as valine and isoleucine tend to fragment toward their C-terminal peptide bonds [11]. Other published work using tandem MS on 
peptides, e.g., ubiquitin, have often indicated unusually abundant product ions resulting from cleavage of peptide linkages on the N-terminal side of Pro residues [12]. This propensity for selective fragmentation has also been reported for singlyprotonated peptides [13-18] and multiply-charged protein ions [19]. This phenomenon is sometimes known as the proline effect and was first attributed to the relatively high proton affinity of Pro [20]. Vaisar and Urban investigated a number of peptides that contained a modified amino acid residue of relatively high proton affinity, most notably one that contained a six-membered piperidine ring as opposed to Pro's fivemembered pyrolidine ring, and concluded that proton affinity does not explain the proline effect [17]. They attributed the preferred $\mathrm{N}$-terminal (as opposed to $\mathrm{C}$-terminal) cleavage to Pro in terms of increased ring strain in forming a bicyclic $b$ ion when the C-terminal peptide bond is cleaved. The conformation of the Pro residue may also play an important role in fragmentation. Wysocki and co-workers studied this with a database of low-energy CID tandem mass spectra of doublycharged peptides [21]. They found that the residue (Xxx) adjacent to Pro affects the extent of fragmentation at the XxxPro bond. Particularly enhanced Xxx-Pro bond cleavage when $\mathrm{Xxx}$ is Val, Ile, and Leu was ascribed to the steric hindrance of their bulky side chains, since it causes Pro to take a 'reactive' trans form that leads to product ions. However, they did not elucidate the 'reactive' conformation of Pro or the fragmentation mechanism. Infrared multiphoton dissociation (IRMPD) of peptides results in few backbone ( $b$ - and $y$-type) cleavages but increased side-chain fragmentation. In addition, IRMPD showed an increased selectivity toward N-terminal backbone cleavages to Pro [22].

In addition and complementary to CID, reactions of polypeptide ions with electrons and small radical ions, such as electron capture dissociation (ECD) $[23,24]$ and electrontransfer dissociation (ETD) [25-27], have become very useful tools for peptide structural analysis. The ion-electron and ionion reactions are different from slow heating methods, such as CID, by the fact that the intermediate fragmenting species are odd-electron ions. In fact, the presence of a radical site diminishes the strength of nearby bonds. In particular, for peptide polyanions, preferential backbone cleavage of $\mathrm{C}-\mathrm{C}$ bonds yielding $a$ and $x$ ions as well as side chain fragmentation were demonstrated [28-32]. Specific cleavage of peptide linkages on the N-terminal of Pro residues was also observed in $\operatorname{ECD}[30,33,34]$.

Vacuum ultraviolet photodissociation (VUVPD) is an elegant, high-energy method for inducing fragmentation in peptides [35]. Following electronic transition, direct dissociation in the excited state competes with radiative relaxation and internal conversion to the electronic ground state. VUVPD of Procontaining peptide ions was reported with the production of unusual product ions [36]. In particular, unusual $b_{n}+2$ and $a_{n}+$ 2 ions were observed. Their formation was explained by homolytic cleavage of the $\mathrm{C}_{\alpha}-\mathrm{C}$ bond in conjunction with a rearrangement between electrons and an amide hydrogen. Formation of these abnormal ions has been compared to the effect of Pro on gas-phase conformation of peptides. UVPD of peptides at $193 \mathrm{~nm}$ was achieved with production of $a, b, c, x, y$, and $z$ sequence ions, in addition to immonium ions and $v$ and $w$ side-chain loss ions [37]. However, the unusual fragment ions were not reported for the studied sequences.

Herein, we investigate the UVPD of Pro-containing peptides at $213 \mathrm{~nm}$. This wavelength corresponds to the emergence of the lowest-lying electronic excited states of the molecules and thus allows the investigation of the relation between the nature of excited states and the observed fragmentation patterns. The calculation of the electronic excited states and molecular dynamics for the model RPK peptide (arginineproline-lysine) are reported here in order to gain insight into the first steps of UV photodissociation of Pro-containing peptides. Our complementary theoretical and experimental investigations open a new route for identification of the photofragmentation pathways allowing identification of the link between the nature of electronic excited states and the observed fragmentation pathways.

\section{Material and Methods}

\section{Chemicals}

Methanol $(\mathrm{MeOH})$ was obtained from Fisher Scientific (Strasbourg, France) and milli-Q water (18.2 M $2 . \mathrm{cm})$ was used. Deuterated methanol $\left(\mathrm{CH}_{3} \mathrm{OD}\right)$, deuterium oxide $\left(\mathrm{D}_{2} \mathrm{O}\right)$, Bradykinin and Substance $\mathrm{P}$ acetate salts were purchased from Sigma-Aldrich (St Quentin-Fallavier, France). LGPLVEQGR, LGADMEDVR and EANYIGSDK peptides were synthesized by Millegen (Labège, France). RPK peptide was synthesized by GeneCust (Dudelange, Luxembourg).

\section{Instrumentation}

Experiments were performed on a hybrid quadrupole-orbitrap Q-Exactive ${ }^{\circledR}$ mass spectrometer (Thermo Fisher Scientific, San Jose, CA, USA) equipped with a HESI ion source. The instrument was modified to allow UV laser irradiation of ions. A schematic of the photodissociation set-up is given in Figure 1 quartz window was fitted on the rear of the HCD (High Collision Dissociation) cell to permit introduction of a laser beam. The detector plate, initially positioned at the exit of the $\mathrm{HCD}$ cell and on the laser beam trajectory, was removed. The laser is a BrillantB Nd:YAG (from Quantel, Les Ulis, France). The 5 th harmonic at $\lambda=213 \mathrm{~nm}$ was used with a repetition rate of $20 \mathrm{~Hz}$. This harmonic is generated by combination of the fundamental and 4th harmonic. For experiments at $266 \mathrm{~nm}$, the 4th harmonic was used. The laser beam passes through lenses, diaphragms and is injected in the HCD cell using two dichroic mirrors. The laser beam energy irradiating the ions was $\sim 1 \mathrm{~mJ} /$ pulse. The laser is slightly off axis in order to avoid photofragmentation in the C-trap. 


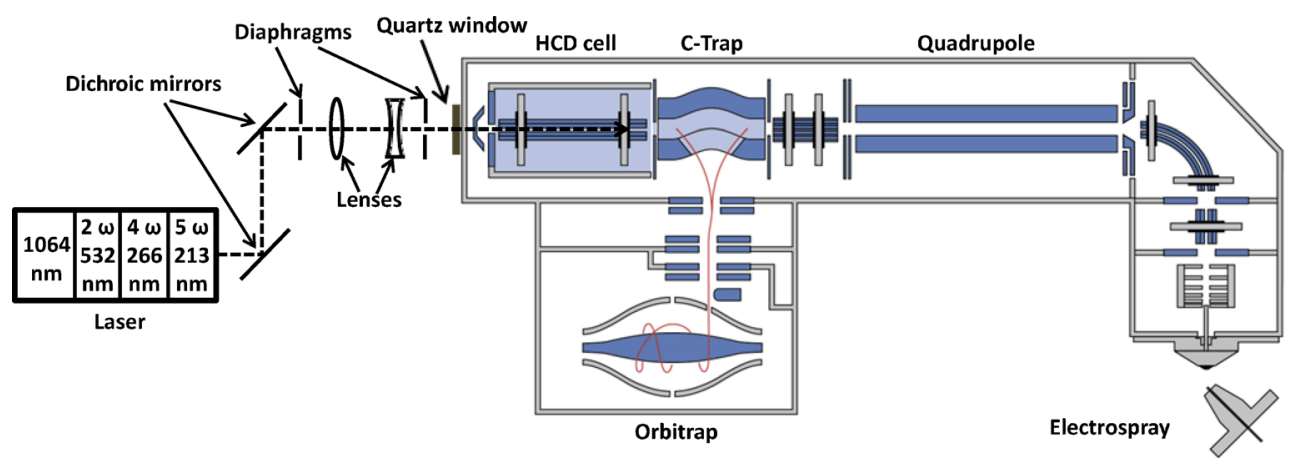

Figure 1. Schematic of the photodissociation experimental set-up in the Q-Exactive mass spectrometer

\section{Mass Spectrometry Operating Conditions}

Ionization was achieved using an electrospray in positive ionization mode with an ion spray voltage of $4500 \mathrm{~V}$. The sheath gas and auxiliary gas (nitrogen) flow rates were set at 20 and 15 (arbitrary unit), respectively, with a HESI vaporizer temperature of $250^{\circ} \mathrm{C}$. The ion transfer capillary temperature was $250^{\circ} \mathrm{C}$. The S-lens RF was set at 90 (arbitrary unit). The orbitrap resolution was 140 000. The Automatic Gain Control (AGC) target was $3 \mathrm{e} 6$ and the maximum injection time was set at $250 \mathrm{~ms}$. For photodissociation experiments, the HCD parameters were optimized in order to avoid CID and were set at $2 \mathrm{eV}$ for the collision energy and $1000 \mathrm{~ms}$ for the activation time. CID experiments were performed using a normalized collision energy of $25 \%$ and $3 \mathrm{~ms}$ activation time. An $m / z$ window of $2.0 \mathrm{Th}$ was applied for precursor isolation. Peptides were dissolved in 50/50 MeOH/water (vol/vol) at a concentration of $100 \mu \mathrm{M}$ and directly electrosprayed at a flow rate of $5 \mu \mathrm{L} / \mathrm{min}$.

\section{Computation}

Investigation of the structures of the RPK model system (arginine + proline + lysine) was done using the simulated annealing method coupled to molecular dynamic simulations using the semi-empirical AM1 method [38]. The structures found were then re-optimized using the semiempirical OM2 (orthogonalization model 2) method [39]. To calculate the absorption spectra, the OM2 method combined with the graphical unitary group approach (GUGA) multi-reference configuration interaction (MRCI) $[40,41]$ within the MNDO program [42] was used. The active space which consists of five occupied and five virtual orbitals was chosen, and all single, double, and
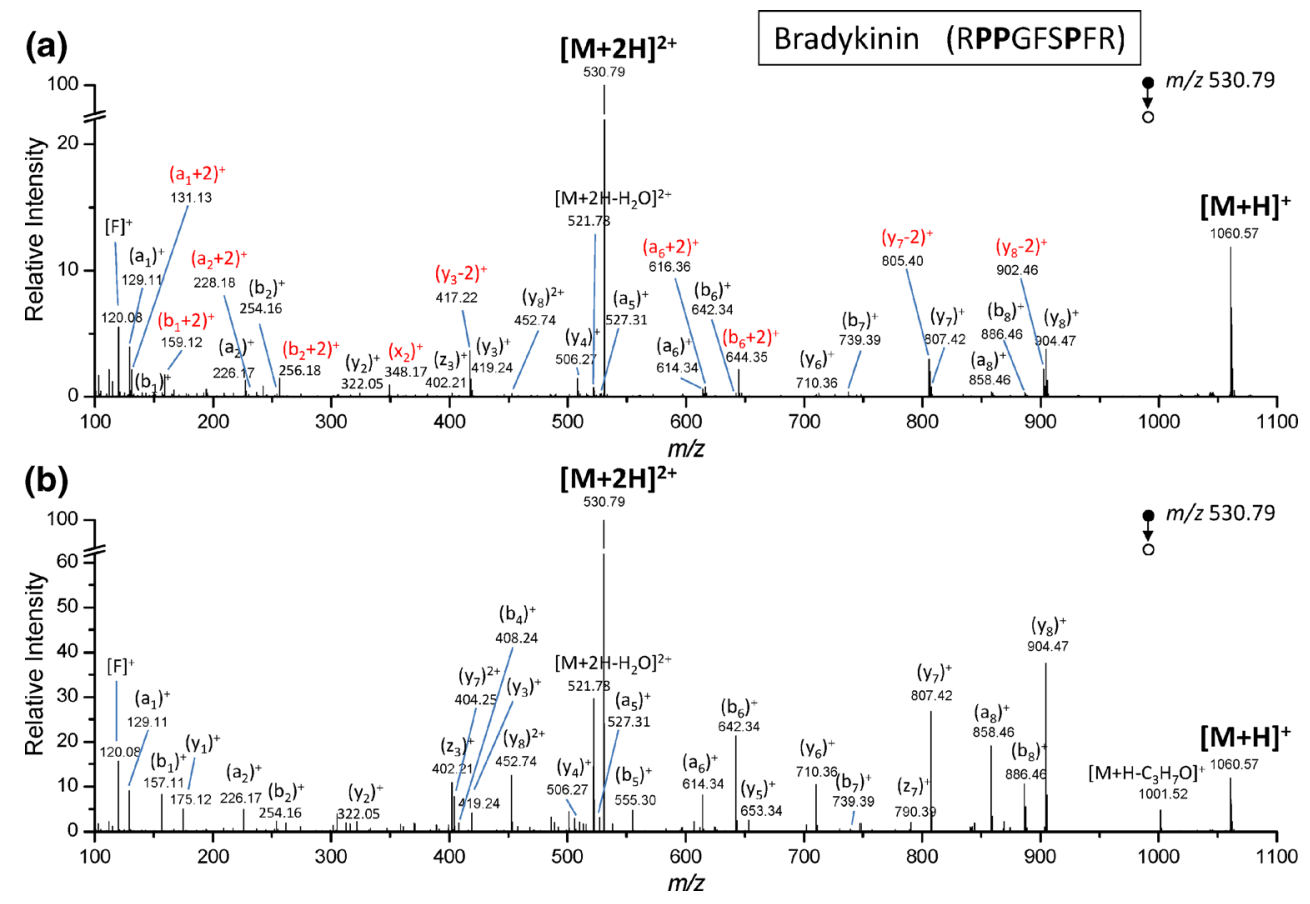

Figure 2. (a) Photodissociation spectrum of the doubly-protonated Bradykinin $[\mathrm{M}+2 \mathrm{H}]^{2+}$ ion $(\mathrm{m} / z 530.79)$ at $213 \mathrm{~nm}$ for $1000 \mathrm{~ms}$ (Collision energy $2 \mathrm{eV}$ ). (b) CID spectrum of doubly-protonated Bradykinin $[\mathrm{M}+2 \mathrm{H}]^{2+}$ ion $(m / z 530.79)$ under a normalized CID collision energy of $25 \%$ for $3 \mathrm{~ms}$ 
triple excitations out of the self-consistent field reference configurations were included in the calculations.

Since the experiments were done at a temperature close to $300 \mathrm{~K}$, we simulated the thermally-broadened absorption spectra. The configurations were sampled from a long molecular dynamic trajectory run at a constant temperature of $300 \mathrm{~K}$ using the semi-empirical OM2 method. To simulate the temperature broadening of the spectrum, the absorption spectrum for each configuration was calculated and these spectra were superimposed. The non-adiabatic dynamics "on the fly" in electronic excited states were determined using Tully's surface-hopping algorithm with non-adiabatic couplings [43]. The initial conditions for non-adiabatic dynamics were obtained by sampling 100 coordinates and momenta along a 30 ps ground-state trajectory at a constant temperature of $300 \mathrm{~K}$ using the OM2 method. The nuclear trajectories were propagated by numerical solution of Newton's equations of motion using the Verlet velocity algorithm [44] with a time step of 0.1 fs. The nonadiabatic dynamics were determined starting from $\mathrm{S}_{2}$ or $\mathrm{S}_{3}$ state matching experimental conditions.

\section{Results and Discussion}

\section{The Photodissociation of Pro-containing Peptides}

The $213 \mathrm{~nm}$ photodissociation spectrum of the doublyprotonated $[\mathrm{M}+2 \mathrm{H}]^{2+}(\mathrm{m} / \mathrm{z} 530.79)$ of Bradykinin (RPPGFSPFR) is shown in Figure 2a. A series of singlycharged $\left(\mathrm{y}_{\mathrm{n}}\right)^{+},\left(\mathrm{b}_{\mathrm{n}}\right)^{+}$and $\left(\mathrm{a}_{\mathrm{n}}\right)^{+}$ions are mainly observed with a $10 \%$ relative intensity. $\left(\mathrm{y}_{\mathrm{n}}\right)^{+}$ions are detected for $\mathrm{n}=2$ to 4 and 6 to $8 .\left(b_{n}\right)^{+}$ions are detected for $n=1,2$ and 6 to 8 , while $\left(a_{n}\right)^{+}$ ions are detected for $\mathrm{n}=1,2,5,6$ and 8 . The $\left(\mathrm{z}_{3}\right)^{+}$ion is also detected at $m / z 402.21$ as well as doubly-charged $\left(\mathrm{y}_{8}\right)^{2+}$ at $m / z$ 452.74. The peptide sequence can be confirmed with these backbone fragment ions. The immonium ion of the phenylalanine residue $[\mathrm{F}]^{+}$is detected at $\mathrm{m} / \mathrm{z} 120.08$. Loss of a water

Table 1. Exact masses and assignments of fragment ions detected in the photodissociation and CID spectra of doubly-protonated Bradykinin $[\mathrm{M}+2 \mathrm{H}]^{2+}($ Figure 2$)$. Error $=(m / z$ theoretical $-m / z$ experimental $) /(m / z$ theoretical $)$

\begin{tabular}{|c|c|c|c|c|c|c|}
\hline \multirow[t]{2}{*}{ Assignment } & \multirow[t]{2}{*}{ Elemental composition } & \multirow[t]{2}{*}{ Theoretical m/z } & \multicolumn{2}{|l|}{ Photodissociation } & \multicolumn{2}{|l|}{ CID } \\
\hline & & & Experimental $\mathrm{m} / \mathrm{z}$ & Error (ppm) & Experimental $\mathrm{m} / \mathrm{z}$ & Error (ppm) \\
\hline$[\mathrm{M}+\mathrm{H}]^{+}$ & $\mathrm{C}_{50} \mathrm{H}_{74} \mathrm{O}_{11} \mathrm{~N}_{15}$ & 1060.5687 & 1060.5693 & 0.566 & 1060.5694 & 0.660 \\
\hline$\left[\mathrm{M}+\mathrm{H}-\mathrm{C}_{3} \mathrm{H}_{7} \mathrm{O}\right]^{+}$ & $\mathrm{C}_{47} \mathrm{H}_{67} \mathrm{O}_{10} \mathrm{~N}_{15}$ & 1001.5190 & ND & NA & 1001.5197 & 0.699 \\
\hline$\left(\mathrm{y}_{8}\right)^{+}$ & $\mathrm{C}_{44} \mathrm{H}_{62} \mathrm{O}_{10} \mathrm{~N}_{11}$ & 904.4676 & 904.4673 & -0.332 & 904.4680 & 0.442 \\
\hline$\left(y_{8}-2\right)^{+}$ & $\mathrm{C}_{44} \mathrm{H}_{60} \mathrm{O}_{10} \mathrm{~N}_{11}$ & 902.4550 & 902.4553 & 0.377 & ND & NA \\
\hline$\left(b_{8}\right)^{+}$ & $\mathrm{C}_{44} \mathrm{H}_{60} \mathrm{O}_{9} \mathrm{~N}_{11}$ & 886.4570 & 886.4573 & 0.338 & 886.4575 & 0.564 \\
\hline$\left(a_{8}\right)^{+}$ & $\mathrm{C}_{43} \mathrm{H}_{60} \mathrm{O}_{8} \mathrm{~N}_{11}$ & 858.4621 & 858.4628 & 0.815 & 858.4625 & 0.466 \\
\hline$\left(\mathrm{y}_{7}\right)^{+}$ & $\mathrm{C}_{39} \mathrm{H}_{55} \mathrm{O}_{9} \mathrm{~N}_{10}$ & 807.4148 & 807.4153 & 0.619 & 807.4152 & 0.495 \\
\hline$\left(y_{7}-2\right)^{+}$ & $\mathrm{C}_{39} \mathrm{H}_{53} \mathrm{O}_{9} \mathrm{~N}_{10}$ & 805.3991 & 805.3995 & 0.497 & ND & NA \\
\hline$\left(z_{7}\right)^{+}$ & $\mathrm{C}_{39} \mathrm{H}_{52} \mathrm{O}_{9} \mathrm{~N}_{9}$ & 790.3883 & ND & NA & 790.3880 & -0.380 \\
\hline$\left(b_{7}\right)^{+}$ & $\mathrm{C}_{35} \mathrm{H}_{51} \mathrm{O}_{8} \mathrm{~N}_{10}$ & 739.3886 & 739.3892 & 0.811 & 739.3889 & 0.406 \\
\hline$\left(\mathrm{y}_{6}\right)^{+}$ & $\mathrm{C}_{34} \mathrm{H}_{48} \mathrm{O}_{8} \mathrm{~N}_{9}$ & 710.3620 & 710.3616 & -0.563 & 710.3624 & 0.563 \\
\hline$\left(y_{5}\right)^{+}$ & $\mathrm{C}_{32} \mathrm{H}_{45} \mathrm{O}_{7} \mathrm{~N}_{8}$ & 653.3406 & $\mathrm{ND}$ & NA & 653.3409 & 0.459 \\
\hline$\left(b_{6}+2\right)^{+}$ & $\mathrm{C}_{30} \mathrm{H}_{46} \mathrm{O}_{7} \mathrm{~N}_{9}$ & 644.3515 & 644.3518 & 0.466 & ND & NA \\
\hline$\left(b_{6}\right)^{+}$ & $\mathrm{C}_{30} \mathrm{H}_{44} \mathrm{O}_{7} \mathrm{~N}_{9}$ & 642.3358 & 642.3360 & 0.311 & 642.3361 & 0.467 \\
\hline$\left(a_{6}+2\right)^{+}$ & $\mathrm{C}_{29} \mathrm{H}_{46} \mathrm{O}_{6} \mathrm{~N}_{9}$ & 616.3566 & 616.3563 & -0.487 & ND & NA \\
\hline$\left(a_{6}\right)^{+}$ & $\mathrm{C}_{29} \mathrm{H}_{44} \mathrm{O}_{6} \mathrm{~N}_{9}$ & 614.3409 & 614.3406 & -0.488 & 614.3412 & 0.488 \\
\hline$\left(b_{5}\right)^{+}$ & $\mathrm{C}_{27} \mathrm{H}_{39} \mathrm{O}_{5} \mathrm{~N}_{8}$ & 555.3038 & ND & NA & 555.3040 & 0.342 \\
\hline$[\mathrm{M}+2 \mathrm{H}]^{2+}$ & $\mathrm{C}_{50} \mathrm{H}_{75} \mathrm{O}_{11} \mathrm{~N}_{15}$ & 530.7880 & 530.7877 & -0.565 & 530.7883 & 0.565 \\
\hline$\left(a_{5}\right)^{+}$ & $\mathrm{C}_{26} \mathrm{H}_{39} \mathrm{O}_{4} \mathrm{~N}_{8}$ & 527.3089 & 527.3093 & 0.759 & 527.3092 & 0.569 \\
\hline$\left[\mathrm{M}+2 \mathrm{H}-\mathrm{H}_{2} \mathrm{O}\right]^{2+}$ & $\mathrm{C}_{50} \mathrm{H}_{73} \mathrm{O}_{10} \mathrm{~N}_{15}$ & 521.7827 & 521.7824 & -0.575 & 521.7831 & 0.767 \\
\hline$\left(\mathrm{y}_{4}\right)^{+}$ & $\mathrm{C}_{23} \mathrm{H}_{36} \mathrm{O}_{6} \mathrm{~N}_{7}$ & 506.2722 & 506.2718 & -0.790 & 506.2724 & 0.395 \\
\hline$\left(\mathrm{y}_{8}\right)^{2+}$ & $\mathrm{C}_{44} \mathrm{H}_{63} \mathrm{O}_{10} \mathrm{~N}_{11}$ & 452.7374 & 452.7371 & -0.663 & 452.7371 & -0.663 \\
\hline$\left(y_{3}\right)^{+}$ & $\mathrm{C}_{20} \mathrm{H}_{31} \mathrm{O}_{4} \mathrm{~N}_{6}$ & 419.2401 & 419.2399 & -0.477 & 419.2397 & -0.954 \\
\hline$\left(y_{3}-2\right)^{+}$ & $\mathrm{C}_{20} \mathrm{H}_{29} \mathrm{O}_{4} \mathrm{~N}_{6}$ & 417.2245 & 417.2242 & -0.719 & ND & NA \\
\hline$\left(b_{4}\right)^{+}$ & $\mathrm{C}_{18} \mathrm{H}_{30} \mathrm{O}_{4} \mathrm{~N}_{7}$ & 408.2354 & ND & NA & 408.2350 & -0.980 \\
\hline$\left(y_{7}\right)^{2+}$ & $\mathrm{C}_{39} \mathrm{H}_{56} \mathrm{O}_{9} \mathrm{~N}_{10}$ & 404.2110 & ND & NA & 404.2108 & -0.495 \\
\hline$\left(z_{3}\right)^{+}$ & $\mathrm{C}_{20} \mathrm{H}_{28} \mathrm{O}_{4} \mathrm{~N}_{5}$ & 402.2136 & 402.2131 & -1.243 & 402.2134 & -0.497 \\
\hline$\left(\times_{2}\right)^{+}$ & $\mathrm{C}_{16} \mathrm{H}_{22} \mathrm{O}_{4} \mathrm{~N}_{5}$ & 348.1666 & 348.1668 & 0.574 & ND & NA \\
\hline$\left(y_{2}\right)^{+}$ & $\mathrm{C}_{15} \mathrm{H}_{24} \mathrm{O}_{3} \mathrm{~N}_{5}$ & 322.1874 & 322.1873 & -0.310 & 322.1870 & -1.242 \\
\hline$\left(b_{2}+2\right)^{+}$ & $\mathrm{C}_{11} \mathrm{H}_{22} \mathrm{O}_{2} \mathrm{~N}_{5}$ & 256.1768 & 256.1767 & -0.390 & ND & NA \\
\hline$\left(b_{2}\right)^{+}$ & $\mathrm{C}_{11} \mathrm{H}_{20} \mathrm{O}_{2} \mathrm{~N}_{5}$ & 254.1612 & 254.1609 & -1.180 & 254.1610 & -0.787 \\
\hline$\left(a_{2}+2\right)^{+}$ & $\mathrm{C}_{10} \mathrm{H}_{22} \mathrm{ON}_{5}$ & 228.1819 & 228.1820 & 0.438 & ND & NA \\
\hline$\left(a_{2}\right)^{+}$ & $\mathrm{C}_{10} \mathrm{H}_{20} \mathrm{ON}_{5}$ & 226.1662 & 226.1663 & 0.442 & 226.1664 & 0.884 \\
\hline$\left(\mathrm{y}_{1}\right)^{+}$ & $\mathrm{C}_{6} \mathrm{H}_{15} \mathrm{O}_{2} \mathrm{~N}_{4}$ & 175.1190 & ND & NA & 175.1191 & 0.571 \\
\hline$\left(b_{1}+2\right)^{+}$ & $\mathrm{C}_{6} \mathrm{H}_{15} \mathrm{ON}_{4}$ & 159.1240 & 159.1239 & -0.628 & ND & NA \\
\hline$\left(b_{1}\right)^{+}$ & $\mathrm{C}_{6} \mathrm{H}_{13} \mathrm{ON}_{4}$ & 157.1084 & 157.1082 & -1.273 & 157.1081 & -1.910 \\
\hline$\left(a_{1}+2\right)^{+}$ & $\mathrm{C}_{5} \mathrm{H}_{15} \mathrm{~N}_{4}$ & 131.1291 & 131.1290 & -0.991 & ND & NA \\
\hline$\left(a_{1}\right)^{+}$ & $\mathrm{C}_{5} \mathrm{H}_{13} \mathrm{~N}_{4}$ & 129.1135 & 129.1133 & -1.549 & 129.1133 & -1.549 \\
\hline$[\mathrm{F}]^{+}$ & $\mathrm{C}_{8} \mathrm{H}_{10} \mathrm{~N}$ & 120.0808 & 120.0809 & 1.166 & 120.0807 & -1.249 \\
\hline
\end{tabular}



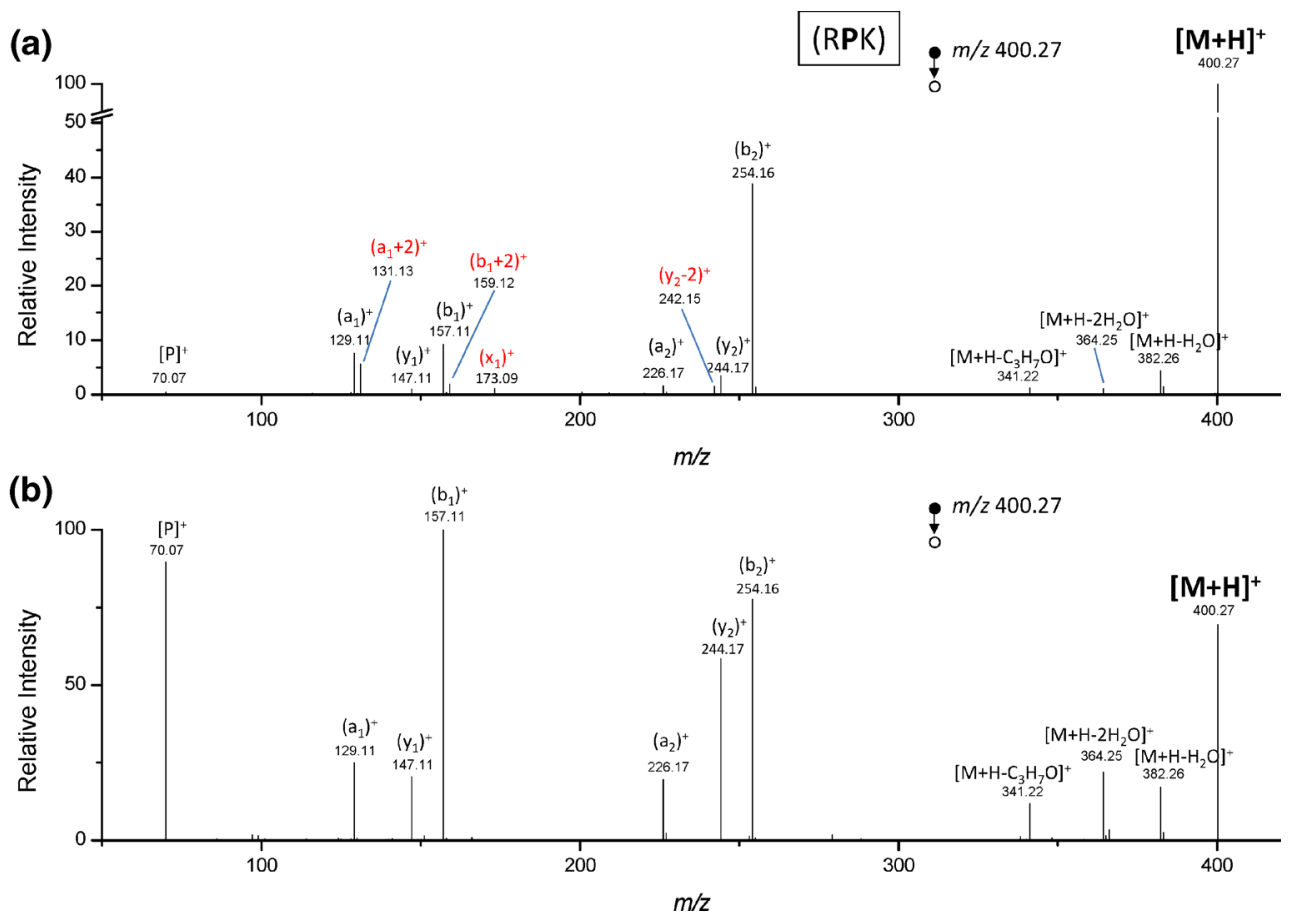

Figure 3. (a) Photodissociation spectrum of protonated RPK $[\mathrm{M}+\mathrm{H}]^{+}$ion $(\mathrm{m} / \mathrm{z} 400.27)$ at $213 \mathrm{~nm}$ for $1000 \mathrm{~ms}$ (Collision energy $2 \mathrm{eV}$ ). (b) CID spectrum of protonated RPK $[\mathrm{M}+\mathrm{H}]^{+}$ion $(\mathrm{m} / \mathrm{z} 400.27)$ under a normalized CID collision energy of $25 \%$ for $3 \mathrm{~ms}$

molecule from the doubly-charged ion precursor is also observed yielding the $\left[\mathrm{M}+2 \mathrm{H}-\mathrm{H}_{2} \mathrm{O}\right]^{2+}$ ion $(\mathrm{m} / z$ 521.78). Charge reduced $[\mathrm{M}+\mathrm{H}]^{+}$is detected at $m / z$ 1060.57. We assigned these fragment ions and confirmed them by the exact masses reported in Table 1. The errors were all less than 2 ppm. For comparison, the CID spectrum of doubly-protonated [M + $2 \mathrm{H}]^{2+}(\mathrm{m} / \mathrm{z} 530.79)$ of Bradykinin is shown in Figure $2 \mathrm{~b}$. Backbone fragment ions are also observed as well as water elimination and the $[\mathrm{M}+\mathrm{H}]^{+}$ion (Table 1).

More interestingly, photodissociation at $213 \mathrm{~nm}$ generates new fragments that are not observed in the CID spectrum. The assignment of these ions was confirmed by the exact masses
(Table 1). Fragment ions detected at $\mathrm{m} / \mathrm{z} 902.46, \mathrm{~m} / \mathrm{z} 805.40$ and $\mathrm{m} / \mathrm{z} 417.22$ correspond to the elemental composition of $y$ ions minus 2 hydrogens and have been labeled in Figure $2 \mathrm{a}\left(\mathrm{y}_{8^{-}}\right.$ $2)^{+},\left(y_{7}-2\right)^{+}$and $\left(y_{3}-2\right)^{+}$, respectively. These $y_{n}-2$ ions are not observed along the whole peptide sequence. This fragmentation pathway occurs only with a Pro residue. In fact, Bradykinin contains 3 Pro residues Pro2, Pro3 and Pro7 among a total of 9 amino acid residues giving rise to $\left(\mathrm{y}_{8}-2\right)^{+},\left(\mathrm{y}_{7}-2\right)^{+}$ and $\left(\mathrm{y}_{3}-2\right)^{+}$ions. These ions are more intense compared to their homologue $\mathrm{y}_{\mathrm{n}}$ ions. The relative intensities of $\left(\mathrm{y}_{8}-2\right)^{+},\left(\mathrm{y}_{7}-2\right)^{+}$ and $\left(\mathrm{y}_{3}-2\right)^{+}$ions correspond to $50 \%, 150 \%$ and $300 \%$ of the relative intensities of $\left(\mathrm{y}_{8}\right)^{+},\left(\mathrm{y}_{7}\right)^{+}$and $\left(\mathrm{y}_{3}\right)^{+}$, respectively.

Table 2. Exact masses and assignments of fragment ions detected in the photodissociation and CID spectra of protonated RPK $[\mathrm{M}+\mathrm{H}]^{+}(\mathrm{Figure} 3)$. Error $=(m / z$ theoretical $-m / z$ experimental $) /(m / z$ theoretical $)$

\begin{tabular}{|c|c|c|c|c|c|c|}
\hline \multirow[t]{2}{*}{ Assignment } & \multirow[t]{2}{*}{ Elemental composition } & \multirow[t]{2}{*}{ Theoretical $\mathrm{m} / \mathrm{z}$} & \multicolumn{2}{|l|}{ Photodissociation } & \multicolumn{2}{|l|}{ CID } \\
\hline & & & Experimental $m / z$ & Error (ppm) & Experimental $\mathrm{m} / \mathrm{z}$ & Error (ppm) \\
\hline$[\mathrm{M}+\mathrm{H}]^{+}$ & $\mathrm{C}_{17} \mathrm{H}_{34} \mathrm{O}_{4} \mathrm{~N}_{7}$ & 400.2667 & 400.2665 & -0.500 & 400.2663 & -0.999 \\
\hline$\left[\mathrm{M}+\mathrm{H}-\mathrm{H}_{2} \mathrm{O}\right]^{+}$ & $\mathrm{C}_{17} \mathrm{H}_{32} \mathrm{O}_{3} \mathrm{~N}_{7}$ & 382.2561 & 382.2564 & 0.785 & 382.256 & -0.262 \\
\hline$\left[\mathrm{M}+\mathrm{H}-2 \mathrm{H}_{2} \mathrm{O}\right]^{+}$ & $\mathrm{C}_{17} \mathrm{H}_{30} \mathrm{O}_{2} \mathrm{~N}_{7}$ & 364.2455 & 364.2457 & 0.549 & 364.2457 & 0.549 \\
\hline$\left[\mathrm{M}+\mathrm{H}-\mathrm{C}_{3} \mathrm{H}_{7} \mathrm{O}\right]^{+}$ & $\mathrm{C}_{14} \mathrm{H}_{27} \mathrm{O}_{3} \mathrm{~N}_{7}$ & 341.2170 & 341.2168 & -0.586 & 341.2173 & 0.879 \\
\hline$\left(b_{2}\right)^{+}$ & $\mathrm{C}_{11} \mathrm{H}_{20} \mathrm{O}_{2} \mathrm{~N}_{5}$ & 254.1612 & 254.1610 & -0.787 & 254.1609 & -1.180 \\
\hline$\left(\mathrm{y}_{2}\right)^{+}$ & $\mathrm{C}_{11} \mathrm{H}_{22} \mathrm{O}_{3} \mathrm{~N}_{3}$ & 244.1656 & 244.1654 & -0.819 & 244.1653 & -1.229 \\
\hline$\left(y_{2}-2\right)^{+}$ & $\mathrm{C}_{11} \mathrm{H}_{20} \mathrm{O}_{3} \mathrm{~N}_{3}$ & 242.1499 & 242.1502 & 1.239 & ND & NA \\
\hline$\left(a_{2}\right)^{+}$ & $\mathrm{C}_{10} \mathrm{H}_{20} \mathrm{ON}_{5}$ & 226.1662 & 226.1660 & -0.884 & 226.1660 & -0.884 \\
\hline$\left(\times_{1}\right)^{+}$ & $\mathrm{C}_{6} \mathrm{H}_{13} \mathrm{O}_{2} \mathrm{~N}_{4}$ & 173.0921 & 173.0924 & 1.733 & ND & NA \\
\hline$\left(b_{1}+2\right)^{+}$ & $\mathrm{C}_{6} \mathrm{H}_{15} \mathrm{ON}_{4}$ & 159.1240 & 159.1238 & -1.257 & ND & NA \\
\hline$\left(b_{1}\right)^{+}$ & $\mathrm{C}_{6} \mathrm{H}_{13} \mathrm{ON}_{4}$ & 157.1084 & 157.1082 & -1.273 & 157.1081 & -1.910 \\
\hline$\left(\mathrm{y}_{1}\right)^{+}$ & $\mathrm{C}_{6} \mathrm{H}_{15} \mathrm{O}_{2} \mathrm{~N}_{2}$ & 147.1128 & 147.1129 & 0.680 & 147.1130 & 1.360 \\
\hline$\left(a_{1}+2\right)^{+}$ & $\mathrm{C}_{5} \mathrm{H}_{15} \mathrm{~N}_{4}$ & 131.1291 & 131.1293 & 1.525 & ND & NA \\
\hline$\left(a_{1}\right)^{+}$ & $\mathrm{C}_{5} \mathrm{H}_{13} \mathrm{~N}_{4}$ & 129.1135 & 129.1133 & -1.549 & 129.1133 & -1.549 \\
\hline$[\mathrm{P}]^{+}$ & $\mathrm{C}_{4} \mathrm{H}_{8} \mathrm{~N}$ & 70.0651 & 70.0652 & 1.427 & 70.0650 & -1.427 \\
\hline
\end{tabular}


Fragment ions detected at $\mathrm{m} / \mathrm{z} 159.12, \mathrm{~m} / \mathrm{z} 256.18$ and $\mathrm{m} / \mathrm{z}$ 644.35 have the elemental composition of $b$ ions plus 2 hydrogens and, in Figure $2 \mathrm{a}$, have been labeled $\left(\mathrm{b}_{1}+2\right)^{+},\left(\mathrm{b}_{2}+2\right)^{+}$ and $\left(b_{6}+2\right)^{+}$, respectively. This fragmentation reaction is very efficient compared to the classical mechanism as the relative intensities of $\left(b_{1}+2\right)^{+},\left(b_{2}+2\right)^{+}$and $\left(b_{6}+2\right)^{+}$ions represent 400,500 and $700 \%$ of the relative intensities of their $b_{n}$ homologues. The same behavior is observed for the fragment ions detected at $\mathrm{m} / \mathrm{z} 131.13, \mathrm{~m} / \mathrm{z} 228.18$ and $\mathrm{m} / \mathrm{z} 616.36$ which correspond to $a_{n}$ ions plus 2 hydrogens and, in Figure 2a, have been labeled $\left(a_{1}+2\right)^{+},\left(a_{2}+2\right)^{+}$and $\left(a_{6}+2\right)^{+}$, respectively. Furthermore, these ions are only observed in the neighborhood of the Pro residues. The $\left(\times_{3}\right)^{+}$ion is detected at $\mathrm{m} / \mathrm{z} 348.17$ in the photodissociation spectrum. Kim et al. [36] also observed these unusual fragment ions in the UVPD of singly-charged Pro-containing peptides at $157 \mathrm{~nm}$.

The same photodissociation experiment was done for the doubly-protonated $[\mathrm{M}+2 \mathrm{H}]^{2+}$ of Substance $\mathrm{P}$ (RPKPQQFFGLM) $(\mathrm{m} / \mathrm{z}$ 674.86) and LGPLVEQGR $(\mathrm{m} / \mathrm{z}$ 484.77) peptides. The spectra are shown in Figures $S 1$ and S2 in the Supporting material. Besides the backbone fragments $\mathrm{y}_{\mathrm{n}}$, $b_{n}$ and $a_{n}$ observed in photodissociation and CID, UVPD spectra show $y_{n}-2, b_{n}+2$ and $a_{n}+2$ fragment ions. For the doubly-protonated Substance P peptide which contains 2 Pro residues Pro 2 and Pro4, $\left(\mathrm{y}_{10}-2\right)^{+}$and $\left(\mathrm{y}_{8}-2\right)^{+}$ions are detected at $\mathrm{m} / \mathrm{z} 1190.60$ and $\mathrm{m} / \mathrm{z} 965.45$ corresponding to y ions minus 2 hydrogens (according to exact masses). $\mathrm{b}$ and a fragment ions plus 2 hydrogens $\left(a_{1}+2\right)^{+},\left(b_{1}+2\right)^{+},\left(a_{3}+2\right)^{+}$and $\left(b_{3}+2\right)^{+}$are detected at $\mathrm{m} / \mathrm{z} 131.12, \mathrm{~m} / \mathrm{z} 159.12, \mathrm{~m} / \mathrm{z} 356.19$ and $\mathrm{m} / \mathrm{z} 384.26$, respectively. The $\left(\times_{7}\right)^{+}$ion is detected at $\mathrm{m} / z 640.28$ in the photodissociation spectrum. All assignment errors were less than $1.3 \mathrm{ppm}$. In the photodissociation spectrum of doublyprotonated LGPLVEQGR, which has a Pro3 residue among a total of 9 amino acid (AA) residues, $\left(\mathrm{y}_{7}-2\right)^{+},\left(\mathrm{a}_{2}+2\right)^{+}$and $\left(\mathrm{b}_{2}+\right.$ $2)^{+}$are detected at $\mathrm{m} / \mathrm{z} 796.43, \mathrm{~m} / \mathrm{z} 173.13$ and $\mathrm{m} / \mathrm{z}$ 145.13, respectively (Figure S2). From these 3 examples, we can conclude that $\left(\mathrm{y}_{\mathrm{n}}-2\right)^{+}$ions are only observed in photodissociation for $\mathrm{n}=($ total number of AA - \#Pro +1). These ions still contain the Pro residue. On the other hand, $\left(b_{n}+2\right)^{+}$and $\left(a_{n}+2\right)^{+}$ions are only observed in photodissociation for $\mathrm{n}=(\#$ Pro -1$)$, and they do not contain the Pro residue. These fragmentation pathways are observed only with cleavage of bonds between the amino acid N-terminal to Pro and the Pro residue. In order to confirm the contribution of the Pro residue in these fragmentation pathways, photodissociation experiments were done at 213 $\mathrm{nm}$ for doubly-protonated ions of LGADMEDVR $(\mathrm{m} / \mathrm{z}$ 503.24) and EANYIGSDK $(m / z$ 498.74) peptides that do not contain Pro. The UVPD spectra are presented in Figures S3 and S4, respectively. In these cases, photodissociation and CID spectra are similar. No $\left(\mathrm{y}_{\mathrm{n}}-2\right)^{+},\left(\mathrm{b}_{\mathrm{n}}+2\right)^{+}$or $\left(\mathrm{a}_{\mathrm{n}}+2\right)^{+}$ions are detected in photodissociation. Therefore, the effect of the excited Pro residue is clearly evident in these new mechanisms. Note that photodissociation experiments were also done at $266 \mathrm{~nm}$ for the Pro-containing peptides and new fragment ions were not observed (data not shown). The fact that no unusual fragments close to the Pro were observed means that a higher energy UV excitation (below $266 \mathrm{~nm}$ ) is required to induce these specific photo-fragments.

\section{Photodissociation and Optical Properties of the Protonated RPK Model Peptide}

In order to understand the proline effect, the specificity of VUV excitation and the mechanisms involved in the formation of the unusual fragment ions, a model RPK peptide was used for photodissociation experiments at $213 \mathrm{~nm}$. The optical properties were calculated in parallel to the experiments. Figure 3a shows the $213 \mathrm{~nm}$ photodissociation mass spectrum of the singly-

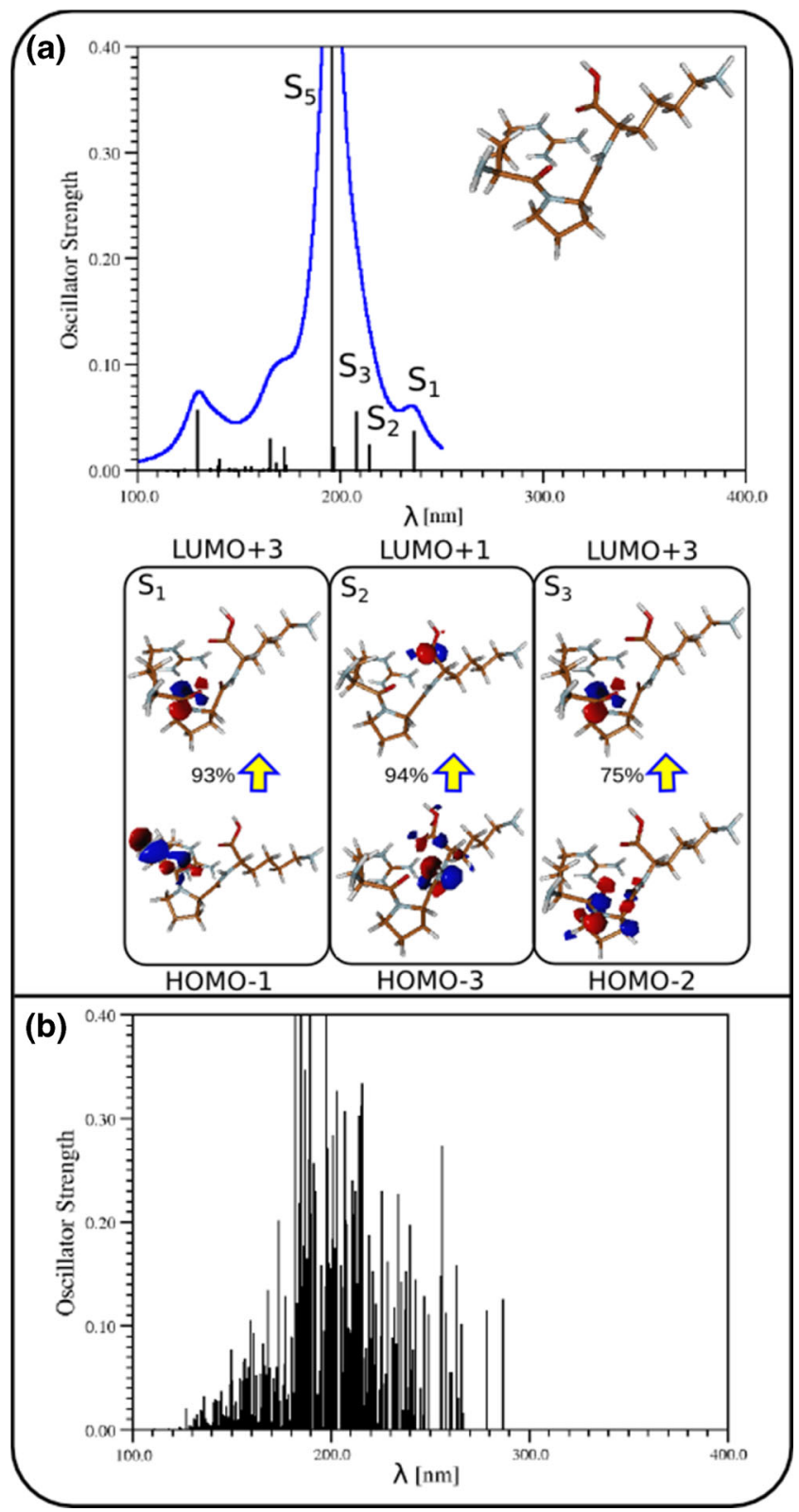

Figure 4. (a) Calculated spectrum for the lowest energy structure of protonated RPK $[\mathrm{M}+\mathrm{H}]^{+}$ion, using the semi-empirical OM2 method at $\mathrm{T}=0 \mathrm{~K}$. Analysis of leading electronic excitations in first three excited states $S_{1}, S_{2}$ and $S_{3}$. (b) Calculated thermally-broadened absorption spectrum at $300 \mathrm{~K}$ 
protonated $[\mathrm{M}+\mathrm{H}]^{+}(\mathrm{m} / \mathrm{z}$ 400.27) of RPK peptide. Singly-charged $\left(\mathrm{y}_{1}-2\right)^{+},\left(\mathrm{b}_{1}-2\right)^{+}$and $\left(\mathrm{a}_{1}-2\right)^{+}$ions are mainly observed with a $20 \%$ relative intensity. The immonium ion of the Pro residue $[\mathrm{P}]^{+}$is detected at $\mathrm{m} / \mathrm{z} 70.07$. We observed that one and two water molecules were lost from the precursor ion yielding the $\left[\mathrm{M}+\mathrm{H}-\mathrm{H}_{2} \mathrm{O}\right]^{+}$ ion $\left(m / z\right.$ 382.26) and $\left[\mathrm{M}+\mathrm{H}-2 \mathrm{H}_{2} \mathrm{O}\right]^{+}$ion $(\mathrm{m} / \mathrm{z} 364.25)$. The fragment ion detected at $\mathrm{m} / \mathrm{z} 341.22$ arises from the loss of $\mathrm{C}_{3} \mathrm{H}_{7} \mathrm{O}$ from the precursor ion. The errors were all less than 1.7 ppm. The CID spectrum of the protonated $[\mathrm{M}+\mathrm{H}]^{+}(\mathrm{m} / \mathrm{z}$ 400.27) of RPK is used as a reference in Figure 3b. Intense backbone fragment ions are also observed as well as water eliminations and $[\mathrm{P}]^{+}$(Table 2). The photodissociation of the protonated RPK peptide ion also shows the unusual $\left(\mathrm{y}_{2}-2\right)^{+},\left(\mathrm{x}_{1}\right)^{+},\left(\mathrm{b}_{1}+2\right)^{+}$and $\left(\mathrm{a}_{1}+\right.$ $2)^{+}$ions detected at $\mathrm{m} / \mathrm{z} 242.15, \mathrm{~m} / \mathrm{z} 173.06, \mathrm{~m} / \mathrm{z} 159.12$ and $\mathrm{m} / \mathrm{z}$ 131.13, respectively (Figure 3a), in contrast to the CID spectrum. All the assignments were confirmed by exact masses (Table 2).

The structural properties of $[\mathrm{M}+\mathrm{H}]^{+}$of the RPK model system were determined via semi-empirical calculations (OM2) as described in the computational section. A number of structures with different binding sites for protons were explored and the lowest energy one has a proton bound to the Arginine side chain $\mathrm{NH}$ group (pKa value $=12$ ). The calculated OM2 spectrum at $\mathrm{T}=0 \mathrm{~K}$ for the lowest energy structure is shown in Figure $4 \mathrm{a}$. The absorption features are characterized by a dominant transition to the $S_{5}$ excited state at $195 \mathrm{~nm}$. Transition to $S_{2}$ and $S_{3}$ excited states with weaker intensity at $214 \mathrm{~nm}$ and $207 \mathrm{~nm}$ are close to the wavelength used for photodissociation experiments $(213 \mathrm{~nm})$. Figure 4a also shows analysis of excitations for the three lowest transitions of the protonated RPK model system in the gas phase. Although, single, double and triple electron excitations were included in calculations, only single excitations have significant contributions in the transitions. Excitations around $200 \mathrm{~nm}$ correspond to those of the Pro residue and from the $\mathrm{C}$ - and N-terminus of the RPK model system. The lowest excited state $S_{1}$ at $236 \mathrm{~nm}$ is characterized by a transition from the $p$ orbital of the $\mathrm{C}$ atom to the $\mathrm{p}$ orbital of the $\mathrm{N}$ atom in the Arginine backbone, while the excitation from the p orbital of the $\mathrm{N}$ atom to the $\mathrm{p}$ orbital of the $\mathrm{C}$ atom of the Lysine backbone is characteristic of the transition to the $\mathrm{S}_{2}$ excited state. The most intense transition to $\mathrm{S}_{5}$ is dominated by excitation from the $\mathrm{p}$ orbital on the $\mathrm{N}$ atom in the Lysine backbone to the $\mathrm{p}$ orbital on the $\mathrm{C}$ atom in Pro.

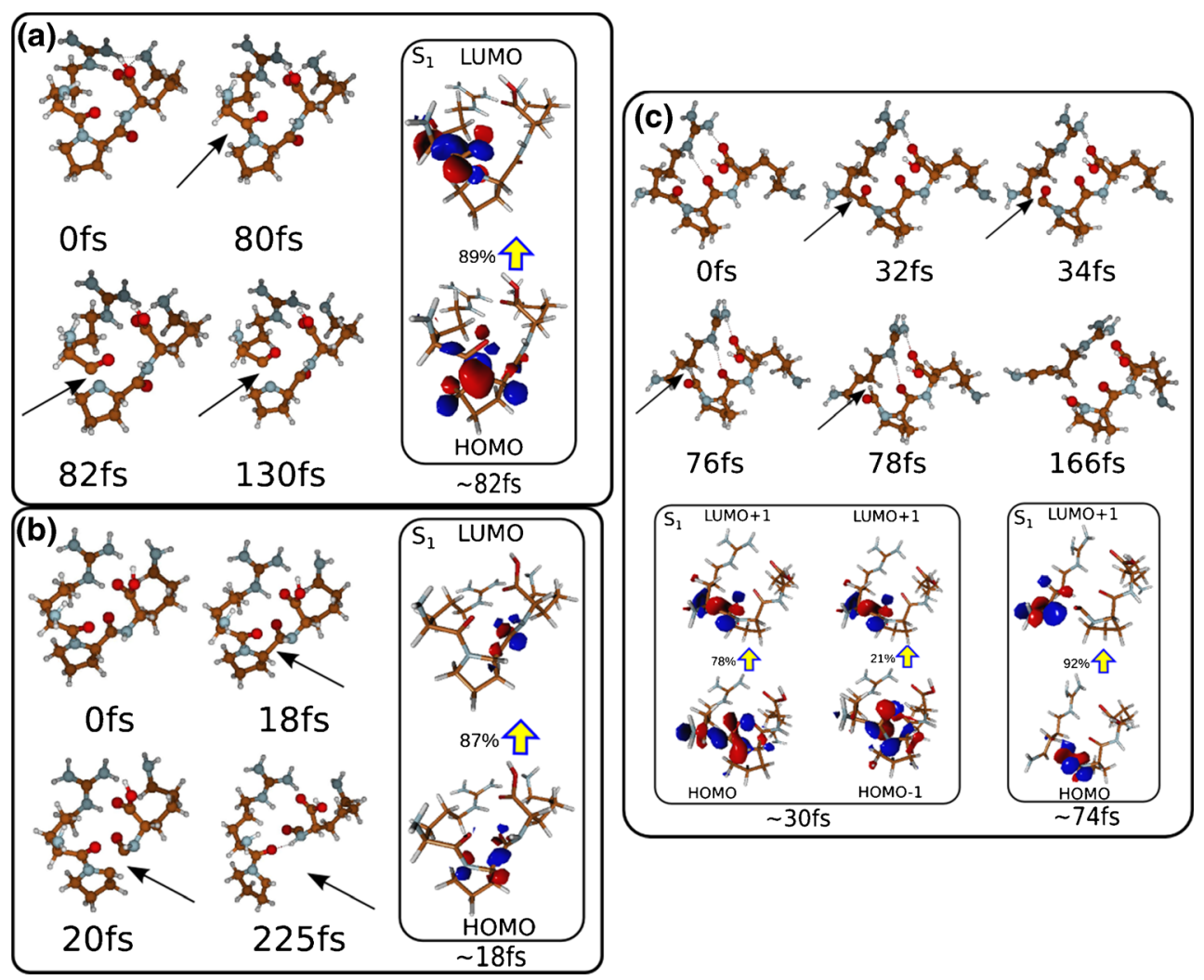

Figure 5. Snapshots of the non-adiabatic MD "on the fly" using OM2 starting in the second electronic excited state $\mathrm{S}_{2}$ from the selected trajectory at $300 \mathrm{~K}$ of protonated RPK $[\mathrm{M}+\mathrm{H}]^{+}$ion (carbon is labelled by brown color, nitrogen by blue and oxygen by red). Evidence of (a) C-N, (b) C-C in proline, and (c) C-C in Arginine bond breaking (indicated by arrows) and proton transfer in the first excited state $\left(\mathrm{S}_{1}\right)$ during the fragmentation process. Dominant excitations of molecular orbitals in the $\mathrm{S}_{1}$ state at the time of bond breaking are also shown. (a) Fragmentation of $\mathrm{C}-\mathrm{N}$ bond at $82 \mathrm{fs}$ is characterized by excitation from non-bonding HOMO to nonbonding LUMO localized at $\mathrm{C}$ and $\mathrm{N}$ atoms, respectively. (b) At $18 \mathrm{fs}$, the $\mathrm{C}-\mathrm{C}$ bond in proline is breaking, which is characterized by excitation from bonding $\mathrm{HOMO}$ to non-bonding LUMO. Trajectory (c) shows $\mathrm{C}-\mathrm{C}$ bond breaking in Arginine at 30 fs and subsequent proton transfer at $74 \mathrm{fs}$. C-C bond breaking is characterized by excitation to two antibonding MOs 
Since the experiment is performed at a temperature close to $300 \mathrm{~K}$, we calculated the thermally-broadened spectrum at
$300 \mathrm{~K}$, shown in Figure 4b, and found that the highest density of transitions occurred around $213 \mathrm{~nm}$ due to $\mathrm{S}_{2}$ and $\mathrm{S}_{3}$ excited

(a)
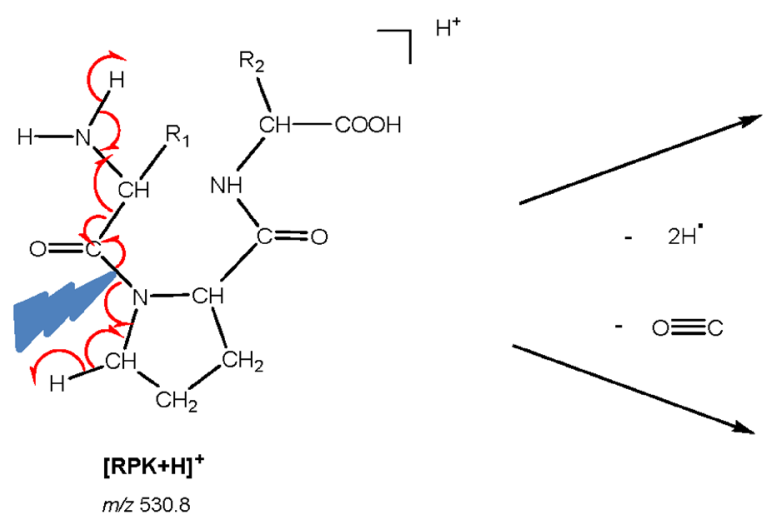

$\mathrm{HN}$<smiles>[R]C=C</smiles>

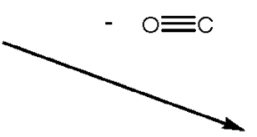

$m / 2530.8$

(b)
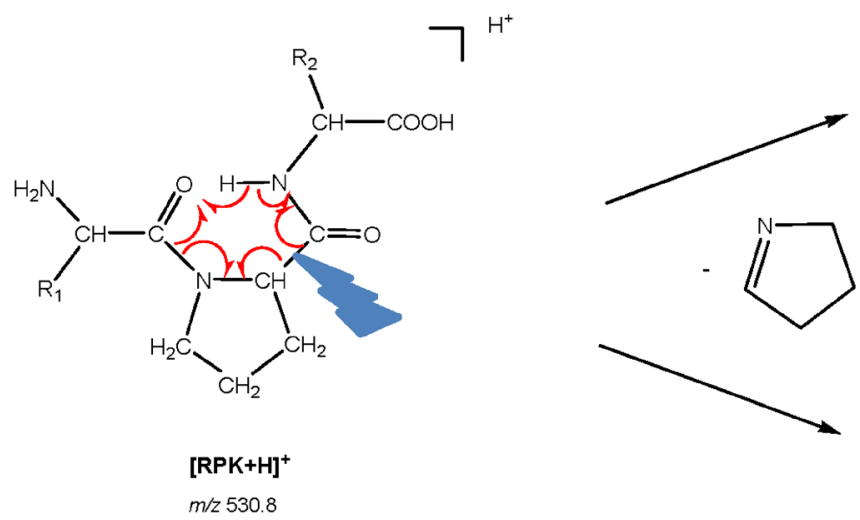

(c)
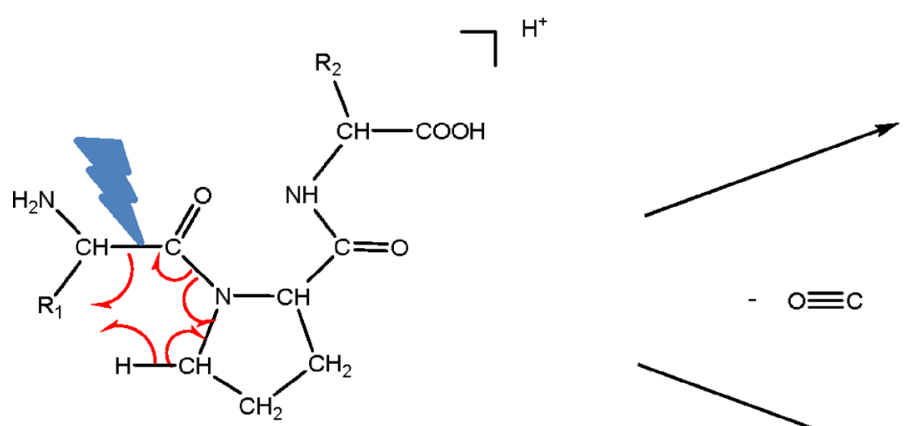<smiles>[R]CN</smiles><smiles>[R]C(N=C=O)C(=O)O</smiles>

$\left(x_{1}\right)^{+}$<smiles>[R]C=N</smiles>

$\left(a_{1}\right)^{+}$ $m / 2129.1$<smiles>[R]C(NC(=O)C1CCC=N1)C(=O)O</smiles>

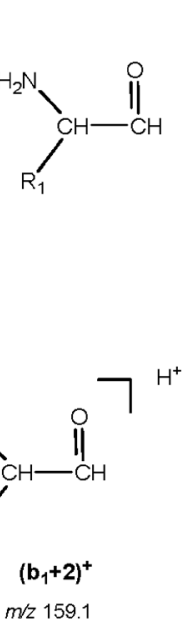<smiles></smiles><smiles>[R]C(CC)C([R])C(=O)O</smiles>

[RPK+H $^{+}$

$\mathrm{m} / \mathrm{z} 530.8$
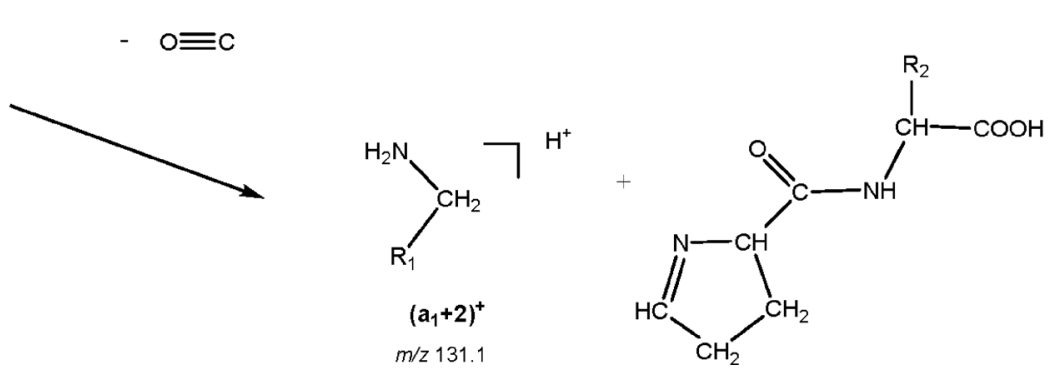

Scheme 1. Proposed mechanisms for the formation of $(a)(y-2)$ and $(a, b, x)$, and $(b+2)$, and $(c)(y-2)$ and $(a+2)$ ions from $[R P K+H]$ ions 


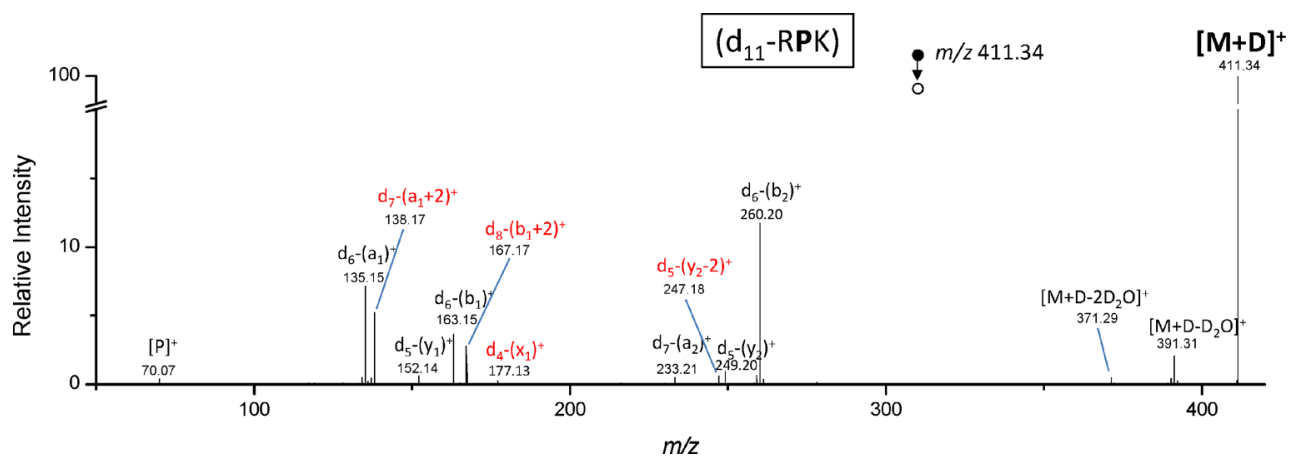

Figure 6. Photodissociation spectrum of singly-charged $\mathrm{d}_{11}-\mathrm{RPK}[\mathrm{M}+\mathrm{D}]^{+}$ion $(\mathrm{m} / \mathrm{z} 411.34)$ at $213 \mathrm{~nm}$ for $1000 \mathrm{~ms}$ (Collision energy $2 \mathrm{eV}$ ) after $\mathrm{H} / \mathrm{D}$ exchange

states. Therefore, in order to follow fragmentation pathways, the non-adiabatic dynamics were studied starting from the $\mathrm{S}_{2}$ and $\mathrm{S}_{3}$ states. However, as they both proceed through similar pathways, the equivalent fragmentation pathways were observed. Therefore, we present results obtained starting from the $\mathrm{S}_{2}$ state only.

\section{Non-adiabatic Molecular Dynamics for the Fragmentation of Protonated RPK Peptide}

The non-adiabatic dynamics at $300 \mathrm{~K}$ starting from the second excited state $\mathrm{S}_{2}$ lead to major fragmentation pathways which take place in the $S_{1}$ state, after non-adiabatic transitions from higher excited states, as illustrated in Figure 5. The pathways include C-N bond (Arg-Pro) breaking, and breaking of C-C bonds in the Arginine and Pro backbones. Snapshots at different times along selected trajectories illustrating bond breaking are shown in Figure 5. The dominant excitations among molecular orbitals in the $S_{1}$ state at the time of bond breaking are also presented, illustrating the nature of the fragmentation pathways. C-N bond breaking (Figure 5a, at $82 \mathrm{fs}$ ) is characterized by excitation from the nonbonding HOMO to the antibonding LUMO localized at $\mathrm{N}$ and $\mathrm{C}$ atoms. The breaking of the $\mathrm{C}-\mathrm{C}$ bond in Pro occurs at 18 fs (Figure 5b) and is characterized by excitations from the nonbonding HOMO to the LUMO localized at the $\mathrm{C}_{\alpha}$ atom and $\mathrm{C}$ atom from the carbonyl group of Pro, respectively. The trajectory showing $\mathrm{C}-\mathrm{C}$ bond breaking in Arginine which is followed by proton transfer is presented in Figure 5c. After proton transfer, the Arginine fragment is unstable, and rearrangement of protons can be expected. At $30 \mathrm{fs}$, the $\mathrm{C}-\mathrm{C}$ bond in Arginine breaks (see Figure $5 \mathrm{c}$ ) and so the $\mathrm{S}_{1}$ state for this structure is characterized by excitations from orbitals localized on the Arginine and Pro backbone to the antibonding (C-C in Arginine backbone) molecular orbital (see the bottom of Figure $5 \mathrm{c}$ ). At $\sim 75 \mathrm{fs}$, proton transfer as well as return to the ground state occur. The above analysis explains that different fragmentation pathways involving specific bond breaking in the $S_{1}$ state occur due to nonadiabatic transitions between different electronic excited states. To summarize, the excitations to $S_{2}$ and $S_{3}$ states result in fast non-adiabatic transitions to the $S_{1}$ state followed by activation of C-C and C-N bonds close to the Pro residues.

\section{Fragmentation Mechanisms of the Protonated RPK Peptide}

Interestingly, the above activations are the first steps in the formation of the fragment ions observed experimentally (i.e. $(y-2),(a+2)$ and $(b+2))$. Trajectories shown in Figure 5a correspond to the homolytic cleavage of the $\mathrm{C}-\mathrm{N}$ peptide bond close to Pro which is the first step in generating (y-2) type fragments. In fact, simultaneous rearrangement and elimination of $\mathrm{CO}$ and two $\mathrm{H}$ radicals, from the $\mathrm{N}$-terminus and $\mathrm{CH}_{2}$ group of the Pro ring, would yield the $\left(\mathrm{y}_{2}-2\right)^{+}$fragment ion at $\mathrm{m} / \mathrm{z}$ 242.15 when the charge is on the lysine side chain at the time of the dissociation, as proposed in Scheme 1a. The complementary $\left(\mathrm{a}_{1}\right)^{+}$ion at $\mathrm{m} / \mathrm{z} 129.11$ would be produced via the same mechanism if the charge was located on the arginine (Arg) residue (Scheme 1a).

The $\left(\mathrm{b}_{2}+2\right)^{+}$fragment ion, detected at $m / z 159.12$, would be formed when the Arg side chain bears the charge. The mechanism involves first $\mathrm{C}-\mathrm{C}$ bond activation then breaking in the Pro residue (shown in Figure 5b) and finally, proton transfer from the amine of the lysine (Lys) residue to the carbonyl group of the Arg, according to Scheme $1 \mathrm{~b}$. The $\left(\times_{1}\right)^{+}$ion at $\mathrm{m} / \mathrm{z} 173.06$ is generated with the same mechanism if the charge is located on the Lys residue rather than the N-terminus.

In the same way, trajectories reported in Figure $5 \mathrm{c}$ lead to the $\mathrm{C}_{\alpha}$-C bond breaking on the $\mathrm{N}$-terminal side of Pro which is a prerequisite for generating $(\mathrm{a}+2)$ type fragments. Additional proton transfer from the $\mathrm{CH}_{2}$ of the Pro ring to the alkyl group

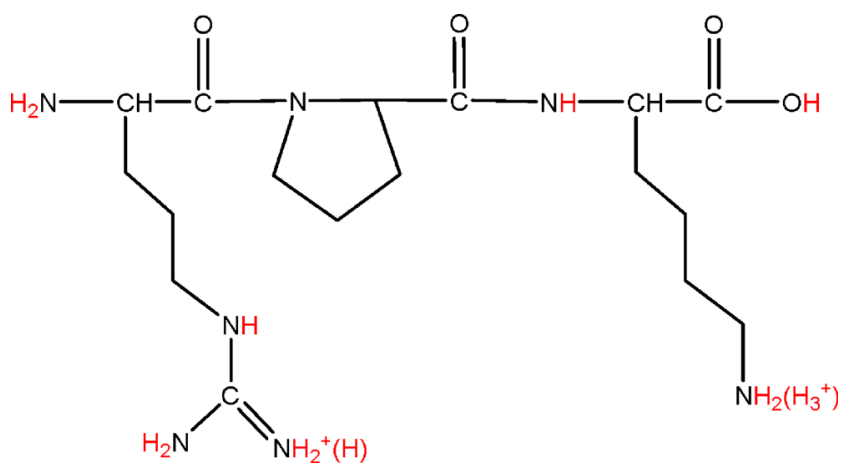

Scheme 2. Structure of $[\mathrm{RPK}+\mathrm{H}]$ ions. Exchangeable hydrogens are highlighted in red 
Table 3. Exact masses and assignments of fragment ions detected in the photodissociation spectrum of singly-charged deuterated RPK $[M+D]^{+}($Figure 6$)$. Error $=(m / z$ theoretical $-m / z$ experimental $) /(m / z$ theoretical $)$

\begin{tabular}{|c|c|c|c|c|}
\hline Assignment & Elemental composition & Theoretical $\mathrm{m} / \mathrm{z}$ & Experimental $\mathrm{m} / \mathrm{z}$ & Error (ppm) \\
\hline$[\mathrm{M}+\mathrm{D}]^{+}$ & $\mathrm{C}_{17} \mathrm{H}_{23} \mathrm{D}_{11} \mathrm{O}_{4} \mathrm{~N}_{7}$ & 411.3357 & 411.3356 & -0.244 \\
\hline$\left[\mathrm{M}+\mathrm{D}-\mathrm{D}_{2} \mathrm{O}\right]^{+}$ & $\mathrm{C}_{17} \mathrm{H}_{23} \mathrm{D}_{9} \mathrm{O}_{3} \mathrm{~N}_{7}$ & 391.3126 & 391.3123 & -0.769 \\
\hline$\left[\mathrm{M}+\mathrm{D}-2 \mathrm{D}_{2} \mathrm{O}\right]^{+}$ & $\mathrm{C}_{17} \mathrm{H}_{23} \mathrm{D}_{7} \mathrm{O}_{2} \mathrm{~N}_{7}$ & 371.2895 & 371.2892 & -0.810 \\
\hline $\mathrm{d}_{6}-\left(\mathrm{b}_{2}\right)^{+}$ & $\mathrm{C}_{11} \mathrm{H}_{14} \mathrm{D}_{6} \mathrm{O}_{2} \mathrm{~N}_{5}$ & 260.1988 & 260.1986 & -0.769 \\
\hline $\mathrm{d}_{5}-\left(\mathrm{y}_{2}\right)^{+}$ & $\mathrm{C}_{11} \mathrm{H}_{17} \mathrm{D}_{5} \mathrm{O}_{3} \mathrm{~N}_{3}$ & 249.1969 & 249.1965 & -1.612 \\
\hline $\mathrm{d}_{5}-\left(\mathrm{y}_{2}-2\right)^{+}$ & $\mathrm{C}_{11} \mathrm{H}_{15} \mathrm{D}_{5} \mathrm{O}_{3} \mathrm{~N}_{3}$ & 247.1813 & 247.1812 & -0.406 \\
\hline $\mathrm{d}_{7}-\left(\mathrm{a}_{2}\right)^{+}$ & $\mathrm{C}_{10} \mathrm{H}_{13} \mathrm{D}_{7} \mathrm{ON}_{5}$ & 233.2102 & 233.2098 & -1.723 \\
\hline$d_{4}-\left(\times_{1}\right)^{+}$ & $\mathrm{C}_{6} \mathrm{H}_{9} \mathrm{D}_{4} \mathrm{O}_{2} \mathrm{~N}_{4}$ & 177.1284 & 177.1287 & 1.703 \\
\hline $\mathrm{d}_{8^{-}}\left(\mathrm{b}_{1}+2\right)^{+}$ & $\mathrm{C}_{6} \mathrm{H}_{7} \mathrm{D}_{8} \mathrm{ON}_{4}$ & 167.1743 & 167.1741 & -1.204 \\
\hline $\mathrm{d}_{6}-\left(\mathrm{b}_{1}\right)^{+}$ & $\mathrm{C}_{6} \mathrm{H}_{7} \mathrm{D}_{6} \mathrm{ON}_{4}$ & 163.146 & 163.1458 & -1.226 \\
\hline $\mathrm{d}_{5}-\left(\mathrm{y}_{1}\right)^{+}$ & $\mathrm{C}_{6} \mathrm{H}_{10} \mathrm{D}_{5} \mathrm{O}_{2} \mathrm{~N}_{2}$ & 152.1442 & 152.1439 & -1.985 \\
\hline$d_{7}-\left(a_{1}+2\right)^{+}$ & $\mathrm{C}_{5} \mathrm{H}_{8} \mathrm{D}_{7} \mathrm{~N}_{4}$ & 138.1731 & 138.1729 & -1.447 \\
\hline$d_{6}-\left(a_{1}\right)^{+}$ & $\mathrm{C}_{5} \mathrm{H}_{7} \mathrm{D}_{6} \mathrm{~N}_{4}$ & 135.1511 & 135.1509 & -1.491 \\
\hline$[\mathrm{P}]^{+}$ & $\mathrm{C}_{4} \mathrm{H}_{8} \mathrm{~N}$ & 70.0651 & 70.0652 & 1.427 \\
\hline
\end{tabular}

of the Arg and elimination of a $\mathrm{CO}$ molecule (presented in Scheme 1c) would produce the $\left(\mathrm{a}_{1}+2\right)^{+}$ion detected at $\mathrm{m} / \mathrm{z}$ 131.13 when the Arg side chain bears the charge. This fragmentation pathway would also lead to the $\left(\mathrm{y}_{2}-2\right)^{+}$fragment ion if the charge is located on the Lys residue at the time of the dissociation.

Since the above mechanisms involve exchangeable hydrogen atoms, they could be tested by performing H/D exchange experiments. The UVPD-MS/MS spectrum of the singlycharged RPK peptide detected at $\mathrm{m} / \mathrm{z} 411.34$ after ESI of the $\mathrm{CH}_{3} \mathrm{OD} / \mathrm{D}_{2} \mathrm{O} 50: 50(\% \mathrm{v} / \mathrm{v})$ solution of the RPK peptide is shown in Figure 6. In this case, all 11 mobile hydrogens have been exchanged, as highlighted in red in Scheme 2. The single charge is located either on $=\mathrm{NH}_{2}{ }^{+}$of the Arg or on the $\mathrm{NH}_{3}{ }^{+}$of the Lys residue (Scheme 2). The singly-charged $\mathrm{d}_{11}-\mathrm{RPK}$ precursor ion was then detected with an $11 \mathrm{Da}$ mass increase. Similarly, a, b and y ions as well as deuterium oxide losses (see assignments in Table 3) are observed in the photodissociation from this precursor. The photodissociation at $213 \mathrm{~nm}$ of the singly-charged $d_{11}$-RPK also shows (Figure 6) the unusual $d_{5^{-}}$ $\left(\mathrm{y}_{2}-2\right)^{+}, \mathrm{d}_{4}-\left(\mathrm{\times}_{1}\right)^{+}, \mathrm{d}_{8}-\left(\mathrm{b}_{1}+2\right)^{+}$and $\mathrm{d}_{7}-\left(\mathrm{a}_{1}+2\right)^{+}$ions detected at $\mathrm{m} / \mathrm{z}$ 247.18, $\mathrm{m} / \mathrm{z}$ 177.12, $\mathrm{m} / \mathrm{z} 167.17$ and $\mathrm{m} / \mathrm{z} 138.17$, respectively (exact masses in Table 3). Comparison of fragmentation patterns in Figures $3 a$ and 6 confirms the proposed mechanism. First, fragment $\left(\mathrm{y}_{2}-2\right)^{+}$presents a 5 Da mass increase in agreement with structures proposed in Scheme 1a and c i.e. one deuterium on the Lys amine, three deuterium on the Lys side chain bearing the charge, and one deuterium on the $\mathrm{C}$-terminus group. Moreover, the $\left(a_{1}\right)^{+}$fragment is detected with a $6 \mathrm{Da}$ mass increase (Figure 6) after H/D exchange as expected from the structure in Scheme 1a i.e. five deuterium on the Arg side chain bearing the charge and one on the N-terminus. In fact, the precursor ion has eliminated a deuterium from the initial $\mathrm{ND}_{2}$ terminus group which confirms the mechanism in Scheme 1a. In addition, according to the mechanism proposed in Scheme $1 \mathrm{~b},\left(\times_{1}\right)^{+}$should have three deuterium on the Lys side chain bearing the charge and one at the $\mathrm{C}$-terminus group, i.e. a $4 \mathrm{Da}$ mass increase, which is observed (Figure 6). Again following Scheme $1 \mathrm{~b}$, fragment $\left(\mathrm{b}_{1}+2\right)^{+}$should contain five deuterium on the Arg side chain bearing the charge, two at the
$\mathrm{N}$-terminus group and one on the Arg carbonyl group where it has been transferred from the Lys amine group, i.e. an $8 \mathrm{Da}$ mass increase, which is also observed on the fragmentation pattern (Figure 6). Therefore, up to this point, all examined fragmentation pathways are in agreement with the mechanisms previously proposed by Kim et al. [36].

Finally, the $\left(a_{1}+2\right)^{+}$fragment is detected with a 7 Da mass increase (Figure 6) which is inconsistent with a proton transfer from the Lys amine as proposed by Kim et al. [36] which would have led to an $8 \mathrm{Da}$ mass increase. Alternatively, a proton transfer from a $\mathrm{CH}_{2}$ group of the Pro ring, as proposed in Scheme 1c, would explain the observed 7 Da mass increase, i.e. five deuterium on the Arg side chain bearing the charge and two deuterium at the N-terminal. Moreover, we can note that the relative intensity between the $\left(a_{1}-2\right)^{+}$and $\left(a_{1}\right)^{+}$ ions is the same $(73 \%)$ before and after H/D exchange (Figures $3 \mathrm{a}$ and 6). This confirms the proposed mechanism where $\mathrm{D}$ transfer is not required. In fact, hydrogen migration is favored over deuterium transfer.

\section{Conclusions}

To conclude, we observed the formation of unusual (y-2), $(a+2)$ and $(b+2)$ fragment ions upon photodissociation of proline-containing peptides at $213 \mathrm{~nm}$. The formation of these ions was not observed at $266 \mathrm{~nm}$, or for non-proline-containing peptides. The RPK peptide was the smallest peptide for which we were able to observe these fragmentation pathways experimentally. Calculation of the electronic excited states for this peptide showed that $S_{2}$ and $S_{3}$ states could be excited at the experimental wavelength. Non-adiabatic molecular dynamic simulation (MD) starting from $\mathrm{S}_{2}$ and $\mathrm{S}_{3}$ excited states showed that this excitation was followed by $\mathrm{C}-\mathrm{C}$ and $\mathrm{C}-\mathrm{N}$ bond activation close to the proline residue. The MD revealed early relaxation mechanisms leading to the observed fragmentation pathways.

Our complementary theoretical and experimental investigations open new routes for identification of photofragmentation 
pathways. They enable the identification of the link between the nature of electronically-excited states and the observed fragmentation pathways. The MD simulations on the fly provide the foundation for a molecular understanding of the photochemistry of peptides under UV excitation. These trajectories revealed specific breaking of C-C and C-N bonds close to the proline residue. Consecutive rearrangements and proton transfers are required to produce the above unusual fragment ions and the fragmentation mechanisms were confirmed by $H / D$ exchange experiments.

\section{Acknowledgments}

V.B.-K. and P. D. would like to thank the CNRS NCBA international laboratory. V.B.-K. gratefully acknowledges support from the Deutsche Forschungsgemeinschaft (DFG FOR1282) and Split-Dalmatia County. The research leading to these results has received funding from the European Research Council under the European Union's Seventh Framework Programme (FP7/2007-2013 Grant agreement N³20659).

\section{References}

1. Paizs, B., Suhai, S.: Fragmentation pathways of protonated peptides. Mass Spectrom. Rev. 24(4), 508-548 (2005)

2. Smith, R.D., Loo, J.A., Loo, R.R.O., Busman, M., Udseth, H.R.: Principles and Practice of Electrospray Ionization - Mass-Spectrometry for Large Polypeptides and Proteins. Mass Spectrom. Rev. 10(5), 359-451 (1991)

3. Cox, K.A., Gaskell, S.J., Morris, M., Whiting, A.: Role of the site of protonation in the low-energy decompositions of gas-phase peptide ions. J. Am. Soc. Mass Spectrom. 7(6), 522-531 (1996)

4. Dongre, A.R., Jones, J.L., Somogyi, A., Wysocki, V.H.: Influence of peptide composition, gas-phase basicity, and chemical modification on fragmentation efficiency: Evidence for the mobile proton model. J. Am. Chem. Soc. 118(35), 8365-8374 (1996)

5. Dongre, A.R., Somogyi, A., Wysocki, V.H.: Surface-induced dissociation: An effective tool to probe structure, energetics and fragmentation mechanisms of protonated peptides. J. Mass Spectrom. 31(4), 339-350 (1996)

6. Jones, J.L., Dongre, A.R., Somogyi, A., Wysocki, V.H.: Sequence Dependence of Peptide Fragmentation Efficiency Curves Determined by Electrospray-Ionization Surface-Induced Dissociation Mass-Spectrometry. J. Am. Chem. Soc. 116(18), 8368-8369 (1994)

7. Summerfield, S.G., Bolgar, M.S., Gaskell, S.J.: Promotion and stabilization of $b(1)$ ions in peptide phenylthiocarbamoyl derivatives: Analogies with condensed-phase chemistry. J. Mass Spectrom. 32(2), 225-231 (1997)

8. Summerfield, S.G., Whiting, A., Gaskell, S.J.: Intra-ionic interactions in electrosprayed peptide ions. Int. J. Mass Spectrom. Ion Process 162(1-3), 149-161 (1997)

9. Hunt, D.F., Yates, J.R., Shabanowitz, J., Winston, S., Hauer, C.R.: Protein Sequencing by Tandem Mass-Spectrometry. Proc. Natl. Acad. Sci. U. S. A. 83(17), 6233-6237 (1986)

10. Johnson, R.S., Martin, S.A., Biemann, K.: Collision-Induced Fragmentation of $(\mathrm{M}+\mathrm{H})+$ Ions of Peptides - Side-Chain Specific Sequence Ions. Int. J. Mass Spectrom. Ion. Process 86, 137-154 (1988)

11. Tabb, D.L., Smith, L.L., Breci, L.A., Wysocki, V.H., Lin, D., Yates, J.R. Statistical characterization of ion trap tandem mass spectra from doubly charged tryptic peptides. Anal. Chem. 75(5), 1155-1163 (2003)

12. Reid, G.E., Wu, J., Chrisman, P.A., Wells, J.M., McLuckey, S.A.: Chargestate-dependent sequence analysis of protonated ubiquitin ions via ion trap tandem mass spectrometry. Anal. Chem. 73(14), 3274-3281 (2001)

13. Counterman, A.E., Clemmer, D.E.: Cis-trans signatures of prolinecontaining tryptic peptides in the gas phase. Anal. Chem. 74(9), 19461951 (2002)
14. Harrison, A.G., Young, A.B...: Fragmentation reactions of deprotonated peptides containing proline. The proline effect. J. Mass Spectrom. 40(9), $1173-1186$ (2005)

15. Hayakawa, S., Hashimoto, M., Matsubara, H., Turecek, F.: Dissecting the proline effect: Dissociations of proline radicals formed by electron transfer to protonated pro-gly and gly-pro dipeptides in the gas phase. J. Am. Chem. Soc. 129(25), 7936-7949 (2007)

16. Ramek, M., Kelterer, A.M., Teppen, B.J., Schafer, L.: Theoretical Structure Investigations of N-Acetyl-L-Proline Amide. J. Mol. Struct. 352, 59-70 (1995)

17. Vaisar, T., Urban, J.: Probing the proline effect in CID of protonated peptides. J. Mass Spectrom. 31(10), 1185-1187 (1996)

18. Vanhoof, G., Goossens, F., Demeester, I., Hendriks, D., Scharpe, S.: Proline Motifs in Peptides and Their Biological Processing. FASEB J. 9(9), 736-744 (1995)

19. Loo, J.A., Edmonds, C.G., Smith, R.D.: Tandem Mass-Spectrometry of Very Large Molecules .2. Dissociation of Multiply Charged ProlineContaining Proteins from Electrospray Ionization. Anal. Chem. 65(4), 425-438 (1993)

20. Schwartz, B.L., Bursey, M.M.: Some Proline Substituent Effects in the Tandem Mass-Spectrum of Protonated Pentaalanine. Biol. Mass Spectrom. 21(2), 92-96 (1992)

21. Breci, L.A., Tabb, D.L., Yates, J.R., Wysocki, V.H.: Cleavage N-terminal to proline: Analysis of a database of peptide tandem mass spectra. Anal. Chem. 75(9), 1963-1971 (2003)

22. Madsen, J.A., Gardner, M.W., Smith, S.I., Ledvina, A.R., Coon, J.J., Schwartz, J.C., Stafford Jr., G.C., Brodbelt, J.S.: Top-Down Protein Fragmentation by Infrared Multiphoton Dissociation in a Dual Pressure Linear Ion Trap. Anal. Chem. 81(21), 8677-8686 (2009)

23. Zubarev, R.A.: Reactions of polypeptide ions with electrons in the gas phase. Mass Spectrom. Rev. 22(1), 57-77 (2003)

24. Zubarev, R.A., Kelleher, N.L., McLafferty, F.W.: Electron capture dissociation of multiply charged protein cations. A nonergodic process. J. Am. Chem. Soc. 120(13), 3265-3266 (1998)

25. Coon, J.J., Shabanowitz, J., Hunt, D.F., Syka, J.E.P.: Electron transfer dissociation of peptide anions. J. Am. Soc. Mass Spectrom. 16(6), 880882 (2005)

26. Mikesh, L.M., Ueberheide, B., Chi, A., Coon, J.J., Syka, J.E.P., Shabanowitz, J., Hunt, D.F.: The utility of ETD mass spectrometry in proteomic analysis. Biochim. Biophys. Acta 1764(12), 1811$1822(2006)$

27. Syka, J.E.P., Coon, J.J., Schroeder, M.J., Shabanowitz, J., Hunt, D.F.: Peptide and protein sequence analysis by electron transfer dissociation mass spectrometry. Proc. Natl. Acad. Sci. U. S. A. 101(26), 9528-9533 (2004)

28. Antoine, R., Joly, L., Tabarin, T., Broyer, M., Dugourd, P., Lemoine, J.: Photo-induced formation of radical anion peptides. Electron photodetachment dissociation experiments. Rapid Commun. Mass Spectrom. 21(2), 265-268 (2007)

29. Anusiewicz, I., Jasionowski, M., Skurski, P., Simons, J.: Backbone and side-chain cleavages in electron detachment dissociation (EDD). J. Phys. Chem. A 109(49), 11332-11337 (2005)

30. Kjeldsen, F., Silivra, O.A., Ivonin, I.A., Haselmann, K.F., Gorshkov, M., Zubarev, R.A.: C-alpha-C backbone fragmentation dominates in electron detachment dissociation of gas-phase polypeptide polyanions. Chem. Eur. J. 11(6), 1803-1812 (2005)

31. Larraillet, V., Antoine, R., Dugourd, P., Lemoine, J.: Activated-Electron Photodetachment Dissociation for the Structural Characterization of Protein Polyanions. Anal. Chem. 81(20), 8410-8416 (2009)

32. Larraillet, V., Vorobyev, A., Brunet, C., Lemoine, J., Tsybin, Y.O., Antoine, R., Dugourd, P.: Comparative Dissociation of Peptide Polyanions by Electron Impact and Photo-Induced Electron Detachment. J. Am. Soc. Mass Spectrom. 21(4), 670-680 (2010)

33. Cook, S.L., Collin, O.L., Jackson, G.P.: Metastable atom-activated dissociation mass spectrometry: leucine/isoleucine differentiation and ring cleavage of proline residues. J. Mass Spectrom. 44(8), 12111223 (2009)

34. Cooper, H.J., Hudgins, R.R., Hakansson, K., Marshall, A.G.: Secondary fragmentation of linear peptides in electron capture dissociation. Int. J. Mass Spectrom. 228(2-3), 723-728 (2003)

35. Reilly, J.P.: Ultraviolet Photofragmentation of Biomolecular Ions. Mass Spectrom. Rev. 28(3), 425-447 (2009) 
36. Kim, T.-Y., Valentine, S.J., Clemmer, D.E., Reilly, J.P.: Gas-Phase Conformation-Specific Photofragmentation of Proline-Containing Peptide Ions. J. Am. Soc. Mass Spectrom. 21(8), 1455-1465 (2010)

37. Madsen, J.A., Boutz, D.R., Brodbelt, J.S.: Ultrafast Ultraviolet Photodissociation at $193 \mathrm{~nm}$ and its Applicability to Proteomic Workflows. J. Proteome Res. 9(8), 4205-4214 (2010)

38. Dewar, M.J.S., Zoebisch, E.G., Healy, E.F., Stewart, J.J.P.: The Development and Use of Quantum-Mechanical Molecular-Models .76. Am1 - a New General-Purpose Quantum-Mechanical Molecular-Model. J. Am. Chem. Soc. 107(13), 3902-3909 (1985)

39. Weber, W., Thiel, W.: Orthogonalization corrections for semiempirical methods. Theor. Chem Acc. 103(6), 495-506 (2000)
40. Patchkovskii, S., Koslowski, A., Thiel, W.: Generic implementation of semi-analytical CI gradients for NDDO-type methods. Theor. Chem Acc. 114(1-3), 84-89 (2005)

41. Koslowski, A., Beck, M.E., Thiel, W.: Implementation of a general multireference configuration interaction procedure with analytic gradients in a semiempirical context using the graphical unitary group approach. J. Comput. Chem. 24(6), 714-726 (2003)

42. Thiel, W. MNDO program., Max-Planck-Institut für Kohlenforschung: Muhlheim, Germany: 2007

43. Tully, J.C.: Molecular-Dynamics with Electronic-Transitions. J. Chem. Phys. 93(2), 1061-1071 (1990)

44. Verlet, L.: Computer Experiments on Classical Fluids .I. Thermodynamical Properties of Lennard-Jones Molecules. Phys. Rev. 159(1), 98 (1967) 